\title{
Література
}

1. Жалдак М. I. Педагогічний потенціал комп'ютерно-орієнтованих систем навчання математики / М. І. Жалдак // Комп'ютерно-орієнтовані системи навчання: зб. наук. пр. - № 7. - К.: НПУ ім. М.П.Драгоманова, 2003. - С. 3-15. 2. Затямина Т. Компьютерные технологии на уроке музыки / Т. Затямина // Искусство в школе. - 2006. - № 5. - С. 41-43. 3. Козлін В. Й. Використання комп'ютера в процесі формування почуття ритму / В. Й. Козлін // Комп’ютер у школі та сім’ї. 2001. - № 5. - С. 27-29. 4. Рейзенкінд Т. Комп’ютерне навчання в професійній підготовці вчителя музики / Т. Й. Рейзенкінд // Рідна школа. - 2003. - № 2. - С. 56-58. 5. Фіцула М. М. Педагогіка вищої школи: [навч. посіб.] / Михайло Михайлович Фіцула. - К. : Академвидав, 2006. - 352 с. 6. Цыпин Г. М. Принципы развивающего обучения в музыке / Психология музыкальной деятельности: Теория и практика / Григорий Михайлович Цыпин: [учеб. пособ. для студ. муз. фак. высш. пед. учеб. заведений] / под ред. Г. М. Цыпина. - М. : Академия, 2003. - 368 с.

УДК 371.332 .001 .89

Ірина Доценко

\section{ЗМІСТ І СТРУКТУРА НАУКОВО-ДОСЛІДНОЇ РОБОТИ СТУДЕНТІВ}

Доценко І. О. Зміст і структура науково-дослідної роботи студентів.

У статті на основі вивчення архівних матеріалів та інших джерел проаналізовано зміст і види науково-дослідної роботи студентів вищих навчальних закладів України у другій половині XX ст. та в сучасних умовах; визначено структуру науково-дослідної діяльності студентів, яка забезпечує ефективність навчального процесу та сприяє виявленню здібних студентів.

Ключові слова: науково-дослідна робота, структура науково-дослідної роботи, види науково-дослідної роботи, студент-дослідник.

Доценко И. О. Содержание и структура научно-исследовательской работы студентов.

В статье на основе изучения архивных материалов и других источников проанализированы содержание и виды научно-исследовательской работы студентов высших учебных заведений Украины во второй половине XX ст. и в современных условиях; определена структура научноисследовательской деятельности студентов, которая обеспечивает эффективность учебного процесса и способствует выявлению способных студентов.

Ключевые слова: научно-исследовательская работа, структура научно-исследовательской работы, виды научно-исследовательской работы, студент-исследователь.

Docenko I. O. Maintenance and structure of research work of students.

In the article on the basis of study of the archived materials and other sources maintenance and types of research work of students of higher educational establishments of Ukraine is analysed in the second half of XX centuries and in modern terms; the structure of research activity of students, which provides the effective type of educational process and instrumental in the exposure of capable students, is analysed.

Key words: research work, structure of research work, types of research work, student-researcher.

Творча праця фахівця незалежно від виду та характеру його роботи - це вимога часу. Фахівець повинен не тільки вміти виконувати все, що робили до нього інші, але й те, що ніхто до нього не робив. Тому необхідність залучення студентів до науково-дослідної роботи і набуття ними визначених навичок дослідника - вимога, яка висувається до кожного студента. Процес формування майбутнього фахівця стає більш ефективним, якщо студент перебуває в статусі дослідника. Цілеспрямована, педагогічно обгрунтована, організована робота студента може і повинна розглядатися як ефективний вид навчального процесу.

Мета статті - проаналізувати зміст та види науково-дослідної роботи студентів вищих навчальних закладів, структуру науково-дослідницької діяльності студентів, яка забезпечує ефективність навчального процесу та сприяє виявленню здібних студентів.

Сучасний етап розвитку вищої освіти характеризується пошуком нових шляхів співробітництва викладачів і студентів, у процесі яких відбувається формування ініціативи, самостійності та творчості останніх, залучення їх до дослідницько-пошукової навчальної 
діяльності. Проблемі формування активної пізнавальної діяльності, покладеної в основу розвитку й удосконалення різних аспектів дослідницьких умінь студентів, приділено увагу в працях таких науковів, як Л. Аврамчук, Т. Алексєєнко, В. Андреєв, П. Лузан, А. Дьомін, В. Рябець та ін.

Набуття студентами комплексу спеціальних знань і навичок, які передбачають: знання законів творчості та розвитку науковедення, мають своє історичне й соціальне коріння; уміння обробляти велику за обсягом і складністю науково-технічну інформацію; володіння всіма методами експерименту; уміння аналізувати й узагальнювати результати дослідження і робити висновки, а також упроваджувати їх у практику.

Уміння - це самостійна, свідома дія для практичного чи теоретичного застосування набутих знань. Ю. Бабанський розглядає класифікацію вмінь за принципом структурних складників навчальної діяльності (планування завдань і способів діяльності, мотивація, організація дій, самоконтроль, а також процес засвоєння знань). Він виокремлює такі різновиди умінь: навчальноорганізаційні (вміння приймати та розв'язувати завдання діяльності, раціонально планувати діяльність і створювати для неї сприятливі умови); навчально-інформаційні (вміння здійснювати бібліографічний пошук, працювати 3 книгою, довідником, технічними джерелами інформації, здійснювати спостереження); навчально-інтелектуальні (вміння мотивувати свою діяльність, уважно сприймати інформацію, раціонально запам'ятовувати і логічно усвідомлювати навчальний матеріал, виокремлюючи в ньому головне, уміння розв'язувати проблемні пізнавальні завдання, самостійно виконувати вправи і здійснювати самоконтроль у навчально-пізнавальній діяльності) [1].

Особливу групу становлять дослідницькі вміння. На думку В. Литовченко, дослідницькі вміння $€$ сукупністю систематизованих знань, умінь i навичок особистості, поглядів $\mathrm{i}$ переконань, які визначають функціональну готовність студента до творчого пошукового розв'язання пізнавальних завдань. Науковець поділяє дослідницькі вміння на групи:

1) операційні дослідницькі вміння, до яких відносять розумові прийоми і операції, що використовуються в дослідницькій діяльності: порівняння, аналіз і синтез, абстрагування й узагальнення, висунення гіпотези, співставлення;

2) організаційні дослідницькі вміння, що включають застосування прийомів організації в науково-дослідній діяльності, планування дослідної роботи, проведення самоаналізу, регуляція власних дій у процесі дослідницької діяльності;

3) практичні дослідницькі вміння, які охоплюють опрацювання літературних джерел, проведення експериментальних досліджень, спостереження фактів, подій та обробка даних спостережень, упровадження результатів у практичну діяльність;

4) комунікативні дослідницькі вміння, що передбачають застосування прийомів співробітництва в процесі дослідницької діяльності для здійснення взаємодопомоги, взаємоконтролю [3].

Узагальнюючи погляди науковців, можна зазначити, що формування умінь - це процес оволодіння людиною виробленими іншими людьми способами дій i виокремити фази формування умінь: усвідомлення завдання і способів його виконання; спроба застосувати одержані пояснення на практиці (вправляння); утворення стереотипу дій.

Поставивши за мету дослідити можливі напрямки організації дослідницької діяльності студентів ВНЗ, визначимо етапи цього процесу: підготовчий, виконавчий і результативний. Кожний етап характеризується своєю специфікою.

Реалізація всіх етапів забезпечується відповідними умовами: наявність організаційної моделі формування дослідницьких умінь із дисциплін професійно-практичного циклу; оптимізація навчального процесу через упровадження модульно-рейтингової технології; використання дослідницьких завдань технологічного, економічного, екологічного змісту, що відображає специфіку підготовки спеціалістів ВНЗ; керованість самостійною роботою студентів.

Як показує аналіз основних вимог Болонського процесу, провідне місце у підготовці майбутніх спеціалістів належить покращенню науково-дослідної роботи студентів, що має сприяти розвитку їхньої самостійності та творчої активності. Реалізація цих вимог має відбуватися за допомогою ефективних технологічних схем самоосвіти, переорієнтації процесу навчання із суто лекційно-інформативної на індивідуально-диференційовану, особистісно зорієнтовану форму, пошуку нових видів науково-дослідної роботи студентів. Проте, все нове 
буде ефективним лише тоді, коли будуватиметься з урахуванням національного досвіду підготовки фахівців.

Вивчення архівних джерел свідчить, що педагогічно доцільний досвід організації та проведення науково-дослідної роботи майбутніх фахівців накопичено факультетами вищих закладів України у другій половині XX ст. Вивчення і творче використання цього досвіду сприятиме удосконаленню змісту, форм і методів науково-дослідної роботи майбутніх фахівців у сучасних умовах.

Вивчення звітів про навчально-виховну роботу факультетів ВНЗ свідчить, що у другій половині XX ст. викладачі цих закладів постійно залучали майбутніх фахівців до різних видів науково-дослідної роботи. Головними завданнями такої діяльності постали: розвиток у студентів прагнення до досліджень у галузі спеціальних дисциплін та накопичення досвіду цієї роботи; розвиток у майбутніх спеціалістів творчого мислення та формування дослідницьких умінь та навичок; виховання потреби постійно вдосконалювати свої знання, поширювати теоретичний кругозір та наукову ерудицію.

Виходячи 3 цих завдань, у навчально-виховному процесі вищого навчального закладу використовуються такі види науково-дослідної роботи студентів:

1) збір дослідницького та експериментального матеріалу під час підготовки до семінарських та практичних занять, спецсемінарів і спецкурсів зі спеціальних дисциплін;

2) накопичення досвіду вивчення та критичного аналізу наукової літератури;

3) експериментальна робота під час підготовки рефератів, курсових і дипломних проектів;

4) виконання домашніх завдань з елементами творчого пошуку;

5) дослідження, пов'язані з практикою виконання індивідуальних методичних завдань, вивчення досвіду роботи працівників;

6) науково-дослідна та творча робота студентів у позанавчальний час: участь у наукових гуртках і товариствах.

Починаючи 3 молодших курсів, майбутні спеціалісти ознайомлювалися 3 елементами наукових досліджень, здобували навички самостійної роботи 3 поглибленого вивчення спеціальних дисциплін.

Ha III, IV, V курсах студенти залучалися безпосередньо до дослідницької роботи. Їм доручалися конкретні теоретичні й експериментальні розробки, що проводилися у лабораторіях і на випускових кафедрах під час виконання практичних, лабораторних, курсових та дипломних робіт, а також у процесі виробничої практики.

Важливим розділом науково-дослідної діяльності студентів ВНЗ було і $є$ виконання курсових робіт на II-V курсах під керівництвом викладачів.

Головними завданнями курсових робіт було формування у студентів наукового світогляду, активізація пізнавальної діяльності, набуття умінь і навичок самостійного проведення дослідницької роботи, поглиблення знань зі спеціалізації та використання цих знань, умінь $\mathrm{i}$ навичок у розв'язанні практичних завдань.

Вивчення звітів про роботу вищих навчальних закладів України показує, що у 70-80-ті роки XX ст. на факультетах цих закладів практикувалася самостійна робота студентів у формі виконання курсових робіт. На початку навчального року студентам II-го курсу давалася тематика курсових робіт, затверджених кафедрою ВНЗ. Майбутні спеціалісти обирали одну 3 тем, самостійно опрацьовували необхідну літературу і до встановленого терміна готували курсову роботу.

Цікавий досвід проведення захисту курсових робіт було накопичено у 80-ті pp. XX ст. деяких ВНЗ України. Курсові роботи захищалися під час іспиту. Одне з трьох питань білета за вибором студента замінювалося захистом курсової роботи. Вважаємо, що подібна методика стимулювала розвиток самостійного мислення майбутніх спеціалістів, поглиблювала творчий підхід до опрацювання необхідної літератури, вчила відбирати, аналізувати і узагальнювати матеріал з обраної теми.

Як показують джерела, курсові роботи, що виконувалися на факультетах вищих навчальних закладів, характеризувалися певними особливостями, тематика і зміст яких формувалися з урахуванням вимог і потреб підприємств, організацій, установ і відображали своєрідність майбутньої спеціальності.

Як свідчать архівні матеріали, у другій половині XX ст. важливим розділом науково- 
дослідної роботи на факультетах ВНЗ була участь студентів у роботі наукових гуртків спеціальних дисциплін.

Під керівництвом викладачів студенти готували доповіді, наукові роботи, які одержували визнання на студентських конференціях, читаннях, диспутах.

Практичний досвід, накопичений факультетами ВНЗ у галузі організації науково-дослідної роботи студентів доводить, що вона сприяла розвитку самостійності мислення майбутніх спеціалістів, стимулювала їх до творчого пошуку. У процесі виконання цісї роботи створювалися належні умови для безпосереднього спілкування студента 3 викладачем та індивідуального впливу на розвиток майбутнього фахівця. Науково-дослідна робота спрямовувала також енергію молоді на корисні справи і надавала йй змогу виявити і перевірити себе в конкретній діяльності.

Як переконує аналіз сучасної науково-методичної літератури, нині на факультетах ВНЗ збереглися майже всі форми науково-дослідної роботи студентів, що використовувалися в другій половині XX ст. Серед них елементи науково-дослідної роботи під час підготовки до аудиторних занять, реферати, курсові та дипломні роботи. Відновлюється втрачена на початку XXI ст. діяльність наукових студентських гуртків. Також з'явилися нові форми науководослідної роботи майбутніх спеціалістів, зокрема виконання студентами передбачених кредитно-модульною системою індивідуальних науково-дослідних завдань (ІНД3).

Науково-дослідницька діяльність студентів (НДДС) вищих навчальних закладів України $\epsilon$ одним з основних чинників підготовки висококваліфікованих кадрів відповідного профілю.

Поняття «науково-дослідницька діяльність студентів» характеризується двома взаємопов'язаними елементами: навчання елементів дослідницької діяльності, організації та методики наукової творчості; наукові дослідження, що здійснюють студенти під керівництвом викладачів.

Для НДДС вищих навчальних закладів характерним є єдність мети і напрямів навчальної, наукової і виховної роботи, тісна взаємодія всіх форм і методів наукової роботи студентів, що реалізуються в навчальному процесі та в позанавчальний час. Це забезпечує їхню участь у науковій діяльності протягом усього періоду навчання, тісно пов'язану як із науководослідницькою діяльністю, що проводиться підрозділами ВНЗ, так і з громадською діяльністю.

Зміст і структура НДДС забезпечує послідовність їі засобів і форм відповідно до логіки і послідовності навчального процесу, що зумовлює спадкоємність її методів і форм від курсу до курсу, від кафедри до кафедри, від однієї дисципліни до іншої, від одних видів занять до інших, поступове зростання обсягу і складності набутих студентами знань, умінь, навичок у процесі виконання ними наукової роботи. Реалізована в комплексі науково-дослідницька діяльність студентів забезпечує розв'язання таких основних завдань: формування наукового світогляду, оволодіння методологією і методами наукового дослідження; надання допомоги студентам у прискореному оволодінні спеціальністю, досягненні високого професіоналізму; розвиток творчого мислення та індивідуальних здібностей студентів у розв'язанні практичних завдань; прищеплення студентам навичок самостійної науково-дослідницької діяльності; розвиток ініціативи, здатності застосувати теоретичні знання у своїй практичній роботі, залучення найздібніших студентів до розв'язання наукових проблем, що мають суттєве значення для науки і практики; необхідність постійного оновлення і вдосконалення своїх знань; розширення теоретичного кругозору і наукової ерудиції майбутнього фахівця; створення та розвиток наукових шкіл, творчих колективів, виховання у стінах вищого навчального закладу резерву науковців, дослідників, викладачів.

Відповідно, науково-дослідницька діяльність студентів - це системне утворення, яке має свою структуру, зміст і форми.

Зміст і форми НДДС відповідають основним напрямам науково-дослідницької діяльності вищого навчального закладу, базою її організації і проведення є кафедри. У керівництві НДДС беруть участь висококваліфіковані викладачі ВНЗ.

Зміст і характер НДДС визначаються: а) проблематикою дослідницької і науково-методичної діяльності кафедр, факультетів, інституту; б) тематикою досліджень, що здійснюються кафедрами у творчій співпраці з закладами культури, освіти, з усіма профільними для ВНЗ установами та організаціями; в) умовами дослідницької роботи студентів, наявністю бази дослідження, можливістю отримання необхідних документів, наявністю комп'ютерної техніки, Internet та Intranet; забезпеченням НДДС науковим керівництвом та ін. 
Науково-дослідницька діяльність студентів ВНЗ здійснюється за трьома основними напрямами:

- науково-дослідницька робота, що є невід'ємним елементом навчального процесу входить до календарно-тематичних та навчальних планів, навчальних програм як обов'язкова для всіх студентів;

- науково-дослідницька робота, що здійснюється поза навчальним процесом у гуртках, проблемних групах (лабораторіях), перекладацьких та інформаційних студіях тощо;

- науково-організаційні заходи: конференції, конкурси та тощо.

Науково-дослідницька робота студентів у межах навчального процесу є обов'язковою для кожного студента й охоплює майже всі форми навчальної роботи: написання рефератів наукової літератури з конкретної теми в процесі вивчення дисциплін соціально-гуманітарного циклу, фундаментальних і професійно-орієнтованих, спеціальних дисциплін, курсів спеціалізації та за вибором; виконання лабораторних, практичних, семінарських та самостійних завдань, контрольних робіт, що містять елементи проблемного пошуку; виконання нетипових завдань дослідницького характеру в період виробничої практики, на замовлення підприємств, установ, організацій, закладів культури тощо; розроблення методичних матеріалів із використанням дослідницьких методів (глосаріїв, кросвордів, програм і методик соціологічних досліджень тощо); підготовку і захист курсових та дипломних робіт, пов'язаних із проблематикою наукових досліджень спеціальних кафедр [4].

Чітка організація НДДС у навчальному процесі сприяє поглибленому засвоєнню студентами спеціальних навчальних дисциплін, дозволяє найповніше виявити свою індивідуальність, сформувати власну думку щодо кожної дисципліни. При цьому особлива увага приділяється залученню студентів до збору, аналізу та узагальнення кращого практичного досвіду, проведення соціологічних та експериментальних досліджень, підготовки доповідей і повідомлень.

Науково-дослідницька робота студентів поза навчальним процесом $є$ одним із найважливіших засобів формування висококваліфікованих фахівців, якою передбачена участь студентів у роботі наукових гуртків, проблемних груп, творчих секцій, лабораторій тощо; участь студентів у виконанні держбюджетних або госпрозрахункових наукових робіт, проведенні досліджень у межах творчої співпраці кафедр, факультетів, комп'ютерного центру iз закладами культури, освіти тощо; робота в студентських інформаційно-аналітичних та культурологічних центрах; написання статей, тез доповідей, інших публікацій; найпоширенішою формою організації НДДС є наукові гуртки, секції, студії, бюро, центри. Кожний з них є невеликим (10-15 осіб) творчим студентським колективом, який працює над однією або кількома суміжними науковими темами, за планами, що складаються на семестр або навчальний рік. Науковим підрозділом керує викладач, помічником якого є студент.

У якій би формі не проводилася наукова діяльність студента, вона обов'язково завершується презентацією звітів, повідомленням на засіданні гуртка або на студентському науковому семінарі. Студентські науково-дослідні або проектно-конструкторські роботи, які успішно виконані в позанавчальний час і які відповідають вимогам навчальних програм, можуть зараховуватися як відповідні лабораторні роботи, курсові та дипломні проекти (роботи) тощо.

Отже, формування наукового світогляду, розвиток творчих здібностей студентів, формування знань про наукові методи та навички наукової роботи - це ефективний шлях підготовки студентів до самостійної дослідної роботи.

Концептуальна ідея дослідження полягає в тому, що в сучасних умовах ринкових відносин господарювання майбутній фахівець повинен бути конкурентоспроможний i вдало використовувати свої знання в практичній діяльності.

Науково-дослідницька діяльність студентів може бути визначена як такий вид навчальнопізнавальної роботи творчого характеру, який спрямований на пошук, вивчення й пояснення фактів і явищ дійсності задля узагальнення й систематизації суб'єктивно нових знань про них.

\section{Література}

1. Бабанский Ю. К. Рациональная организация учебной деятельности / Ю. К. Бабанский. - М. : Знание, 1984. - 96 с. 2. Ковальчук В. В. Основи наукових досліджень: [навч. посіб.] / В. В. Ковальчук, Л. М. Моїсєєв. - К. : Професіонал, 2004. - 208 с. 3. Литовченко В. Н. Формирование исследовательских умений студентов педагогических специальностей университета средствами НИР: дис. ... канд. пед. наук: спец. 13.00.01 / Литовченко Валентина Николаевна. - Минск, 1990. - 197 с. 4. Спіцин С. С. Методика організації науково-дослідної роботи студентів у вищому закладі освіти / Є. С. Спіцин. - К. : Вид. центр КНЛУ, 2003. - 120 с. 